\title{
Addition impact of biochar from different feed stocks on microbial community and available concentrations of elements in a Psammaquent and a Plinthudult
}

\author{
N. Muhammad ${ }^{1,2}$, P.C. Brookes ${ }^{1}$, J. Wu ${ }^{1 *}$ \\ ${ }^{I}$ Institute of Soil and Water Resources and Environmental Science, Provincial Key Laboratory of Subtropical \\ Soil and Plant Nutrition, Zhejiang University, Hangzhou 310058, China. \\ ${ }^{2}$ Department of Microbiology, Kohat University of Science and Technology, Kohat 26000, Pakistan. \\ *Corresponding author: wujianjun@zju.edu.cn
}

\begin{abstract}
Biochars generated from swine manure, fruit peels, Phragmites australis and Brassica rapa were applied to a Psammaquent and a Plinthudult. The Phospholipid (PLFA) markers indicating different microbial communities and available concentrations of elements ( $\mathrm{K}, \mathrm{Ca}, \mathrm{Na}, \mathrm{Mg}, \mathrm{Al}, \mathrm{Cr}, \mathrm{Cu}, \mathrm{Zn}, \mathrm{Cd}, \mathrm{Pb}, \mathrm{Ni}, \mathrm{As}, \mathrm{Mn}, \mathrm{Fe}, \mathrm{B}, \mathrm{Mo}$ ) were measured. Relationships between microbial communities and available concentrations of elements were also calculated. Microbial communities such as bacteria, fungi, protozoa, actinobacteria, G+ve and G-ve were significantly changed within biochar type and application rate compared to the control soils. The ratio of PLFAs indicating nutritional and environmental stress in microbial communities were increased in all biochar treatments to the Plinthudult but reduced in the Psammaquent compared to the control soils. The biochar addition to soils also changed the soil available element concentrations. Such as, swine manure biochar $3 \%$ significantly increased the $\mathrm{Ca}, \mathrm{Mg}, \mathrm{Cu}, \mathrm{Zn}$, As and Mo available concentrations in both soils. Study concludes that different biochar types and addition rates to soils changed the microbial community structure and available element concentrations in soils. Furthermore, biochars containing lower concentration of elements such as fruit peel and B. rapa biochar application to soils can reduce the availability of elements in soils.
\end{abstract}

Keywords: Biochar, microbial community structure, available concentrations of elements

\section{Introduction}

Worldwide atmospheric increases in greenhouse gases are mainly caused by emissions from the combustion of fossil fuels e.g. gas, coal and oil. Pyrolysis is the slow and incomplete combustion of biomass in oxygen limited condition consequently it produces biochar, gas and oil. Biochar is only very slowly decomposed in soil, providing the slow cycling of organic carbon (Ameloot et al., 2013). Its incorporation to soil is one of the recommended technique to control the carbon (C) fluxes among environmental compartments (Mathews, 2008). In addition, specific effects of biochar on the soil 
ecosystem depends upon its physicochemical properties, which are determined by the feedstock type (agricultural residues, livestock excreta) and pyrolysis conditions (temperature, atmosphere and time) (Marris, 2006; McCormack et al., 2013; Titirici et al., 2007). Pyrolysis is the most suitable technique for biochar production. However, 20-30 $\%$ of the energy of original biomass is lost during the pyrolysis process and the formation of aromatic rings (Titirici et al., 2007).

Biochars with fertilizers, have been reported to improve the soil structure and function (Glaser et al., 2002) and possibly slow the turnover of native soil carbon (Liang et al., 2012). Both improved soil nutrient retention and crop yields in highly leached tropical soils (Lehmann, 2007), have been attributed to the incorporation of biochar to agricultural soils (Graber et al., 2010), probably by improving the availability of nutrients to plants (Lehmann et al., 2003; Silber et al., 2010). Enhanced crop growth due to biochar incorporation is also attributed to the neutralization of phytotoxic compounds and $\mathrm{pH}$ coupled with the stimulation of soil organic matter mineralization (McCormack et al., 2013). It also stimulates the mycorrhizal fungal growth and changes in soil microbial populations and their activities (Kolton et al., 2011). Biochar applications also have some disadvantages in soils. For example, biochars decrease soil $\mathrm{N}$ availability in $\mathrm{N}$ deficient soils due to the higher C:N ratio of the biochar. This causes increased $\mathrm{N}$ immobilization, which, in turn, can decrease crop yield (Asai et al., 2009). Potential negative aspects of biochar on soil quality (adverse effects on microbial community structure, nutrient immobilization and increasing native soil organic matter loss) have been raised (Zimmerman, 2010). Currently, there is no way to remove biochars from soil, at least at the field scale. Biochar addition to agriculture soil may decrease the efficiency of foliar applied pesticides and herbicides.
Biochar reduces the leaching of heavy metals and decreasing the environmental contamination and human exposure. It can also affect the food chain by their adsorption and nutrient uptake reduction (Jones et al., 2011). Sufficiently high biochar applications to soils change their $\mathrm{pH}$ and ultimately change the soil biota (Lehmann et al., 2011).

Microbial communities mineralize soil organic matter during nutrient cycling. Trophic interaction between soil fauna regulates microbial community structure and activity, influencing the rates of nutrient cycling and ultimately plant productivity. Furthermore, soil physical alterations occur due to the activities of larger soil organisms (e.g. earthworms). Soil microbial fauna and their interactions modify the soil structure and function, including the stabilization and sequestration of soil organic carbon (McCormack et al., 2013). Several techniques have been developed to study the microbial communities in soil, among them microbial phospholipid fatty acid analysis (PLFAs) is a efficient and proven technique to examine microbial community structure and their response to environmental stress as well as adaptations to new nutritional sources. This can help to investigate beneficial and sustainable ecosystem processes (Kong et al., 2011).

Biochars influence the microbial population in soils (Lehmann et al., 2011) such as anaerobic bacteria (Ameloot et al., 2013), mycorrhiza in sandy loams and composts (Jindo et al., 2012). Furthermore, biochar and smoke extract stimulate the bacterial (Steiner $e t$ al., 2008) and fungal community in soil (Sun et al., 2012). We hypothesized that higher concentration of specific elements in biochars generated from different feed stocks can influence the microbial community structure and soil quality by increasing or decreasing the available element concentrations in different soils. We applied four biochars at two different rates to Plinthudult and Psammaquent to study their impact 
on microbial community structure and available element concentrations in these soils.

\section{Materials and Methods}

\subsection{Soil collection and classification}

The Psammaquent and Plinthudult were collected from Zhejiang province of China. The particulate size of soils has been published previously (Dai et al., 2013). According to the Chinese classification system these soils are Red Earth and the USDA system classifies these soils as Psammaquent and Plinthudult. Soils were collected from the peripheral layers $(0-15 \mathrm{~cm}$ depth) at the sampling locations (Wu et al., 2009a). The soils were transported to the laboratory and soil debris removed by hand. The soils were air dried, and milled $<2 \mathrm{~mm}$. Soil samples were subjected to physico-chemical analyses before experimental use, as given in the Protocols of the Agricultural Chemistry Committee of China (1983) and accordingly clay, loam and sand contents of soil were determined by the hydrometric method.

\subsection{Biochar production}

Feedstocks of swine manure, fruit peels, Phragmites australis and Brassica rapa were collected from Xixi wetland $\left(30^{\circ} 16^{\prime} 14^{\prime \prime} \mathrm{N}, 120^{\circ} 3^{\prime} 45^{\prime \prime} \mathrm{E}\right)$, Hangzhou, China at harvesting stage. Hangzhou receives an average annual rainfall of $1450 \mathrm{~mm}$ and average annual temperature is $16.2{ }^{\circ} \mathrm{C}$. Feedstocks were airdried, crushed into small pieces $(1 \mathrm{~mm})$ and pyrolyzed at $500{ }^{\circ} \mathrm{C}$ for $2 \mathrm{~h}$ in a muffle furnace (Shanghai Yi Zhong Electricity Furnace Inc, Shanghai, China) under limited oxygen. The pyrolysis temperature was raised at $26{ }^{\circ} \mathrm{C} \min ^{-1}$ and then held at $500{ }^{\circ} \mathrm{C}$ for 2 h (Muhammad et al., 2013; Yuan et al., 2011). After cooling, the biochars were ground to a powder by an electric grinder before use.

\subsection{Experimental design}

Soils were incubated at $25{ }^{\circ} \mathrm{C}$ for one week at $70 \%$ of water holding capacity (WHC) for stabilization of soil chemistry and microbiology. After incubation, 1 and $3 \%$ (w/w; oven-dry soil basis) of each biochar was added to each moist soil in triplicate. Control soils were treated identically, except that biochar was not added. Each biochar at 1 and $3 \%$ were carefully mixed. Biochar amended soils were incubated in plastic bags and moisture was maintained at $70 \%$ of WHC by adjusting to weight with deionized water weekly. Sub samples were collected after 180 days from each treatment. Soil samples were stored at -70 ${ }^{\circ} \mathrm{C}$ for PLFA and element analysis.

\subsection{Element extraction and analysis}

The freeze dried soil samples $(0.2 \mathrm{~g})$ were weighed into $50 \mathrm{ml}$ Teflon tubes, and digested with $5 \mathrm{ml} \mathrm{HNO}_{3}$

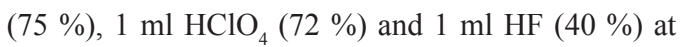
$100{ }^{\circ} \mathrm{C}$ for $6 \mathrm{~h}$. The digested samples were filtered $(0.45 \mu \mathrm{m})$ and the final volumes adjusted to $30 \mathrm{~mL}$. The ammonium acetate-extractable elements were determined following the extraction procedure as described (Van Ranst, 1999). Briefly, freeze dried soil samples ( $3 \mathrm{~g}$ ) were shaken with $30 \mathrm{~mL}$ of $1 \mathrm{~mol}$ $\mathrm{L}^{-1}$ ammonium acetate solution $(\mathrm{pH} 7.0)$ at $25{ }^{\circ} \mathrm{C}$ for $2 \mathrm{~h}(200 \mathrm{rpm})$. The suspension was centrifuged at $8000 \mathrm{~g}$ for 10 minutes and filtered through 0.45 $\mu \mathrm{m}$, final volumes were adjusted to $30 \mathrm{~mL}$. Samples were analyzed by ICP mass Spectrometry for $\mathrm{K}, \mathrm{Ca}$, $\mathrm{Na}, \mathrm{Mg}, \mathrm{Al}, \mathrm{Cr}, \mathrm{Cu}, \mathrm{Zn}, \mathrm{Cd}, \mathrm{Pb}, \mathrm{Ni}, \mathrm{As}, \mathrm{Mn}, \mathrm{Fe}, \mathrm{B}$, and $\mathrm{Mo}$, presented as $\mathrm{mg} \mathrm{kg}^{-1}$. Quality assurance and control (QA/QC) for elements in soil and biochars were obtained by determining the above elemental concentrations in standard reference materials (soil GSBZ 50013, approved by General Administration of Quality Supervision, Inspection and Quarantine of 
the People's Republic of China (AQSIQ)). Analytical results were satisfactory, ranging from 96.5 to $101.2 \%$ of given standard concentrations.

\subsection{Phospholipid fatty acid (PLFA) extraction and nomenclature}

Microbial PLFAs were extracted from biochar treated soils after 120 days. The PLFAs were extracted from $3.0 \mathrm{~g}$ of freeze-dried soil samples, fractionated and methylated (Wu et al., 2009a). In brief, extractable lipids were dissolved in chloroform then fractionated on silica bonded phase columns (SPE-Si, Supelco, Poole, UK). Neutral, glycolipids and phospho (polar) lipids were extracted with chloroform, acetone and methanol, respectively. In each sample, fatty acid 19:0 was added as an internal standard before methylation. PLFAs were subjected to mild alkaline hydrolysis for methyl ester formation and the phospholipids fractions recovered in chloroform. The solvents were removed by evaporation under $\mathrm{N}_{2}$ and the resulting fatty acid methyl esters identified by GC (N6890, Agilent) fitted with an MIDI SHERLOCKS microbial identification system (version 4.5, MIDI). For each sample the concentrations of individual fatty acid methyl esters were given as mol percent.

\subsection{Microbial biomarkers}

All the detected PLFAs from the soils, each treated with 4 biochars, were used to estimate the PLFA markers of the different microbial groups. The sum of PLFA makers' ( $\Sigma=\mathrm{i} 15: 0$, a15:0, 15:0, i16:0, i17:0, cy 17:0, a17:0 and cy 19:0) were used as representatives of general bacteria accordingly (Bossio et al., 1998). Fungi were represented by $(\Sigma=18: 1 \mathrm{w} 9 \mathrm{c}$ and 18:2w6,9c) PLFA markers (Myers et al., 2001; Rinnan

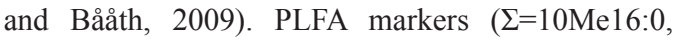
10Me17:0, 10Me18:0 and 10Me19:0) were used for actinobacteria population and the PLFA marker $18: 3 \mathrm{w} 6 \mathrm{c}$ represented the protozoa. The PLFA markers ( $\Sigma=16: 1 w 9 c, 16: 1 w 7 c, 18: 1 w 7 c, 19: 1 w 11 c$, cy17:0, cy19:0w8c) were designated for Gram negative (Gve) bacteria (Mutabaruka et al., 2007; Ratledge and Wilkinson, 1988). The Gram positive (G+ve) bacteria were represented by ( $\Sigma=\mathrm{i} 14: 0$, i15:0, a15:0, i16:0, a17:0 and i17:0) PLFAs (Zelles et al., 1997). The PLFA markers $(\Sigma=10$ Me18:0 and 17:1w8c) were used for sulfate reducers and cy 19:0w8c for anaerobic bacteria. The iso, anteiso, monosaturated, saturated, and cyclopropane PLFA concentrations were also calculated to determined the relative abundance of different PLFA groups. Whereas the cyclopropane: monosaturated (Mo:Cy) and iso: anteiso PLFAs were considered the indicators of nutritional stress. These ratios have formerly been used as indexes of ecological stress (Hedlund, 2002; McKinley et al., 2005; Pettersson and Baath, 2003). All analyses were performed in triplicate and expressed as mol \% of total PLFAs.

\subsection{Statistical analysis}

Three replicates of individual fatty acids were used in all analyses and articulated in mol \%. Average and deviation were calculated by Microsoft Office Excel vr.7, Principal Component Analysis (PCA) and Spearman's Correlation Coefficient were determined by SPSS ver.20 (SPSS IBM). The interaction among soil microbial communities and available element concentrations in biochar type and application rates to both soils were analyzed by redundancy analysis (RDA) through CANOCO vr.4.5 for Windows. In brief, the sums of biomarkers indicating different microbial groups were used to identify microbial species and available element concentrations as environmental variables. A linear scaling method was used for indicating inter relationships with chemical properties 
within biochar type and treatment rate. Species and environmental variables were homogenized by square root transformation of data. Species, environmental variables and samples were standardized to normalize the values. Specie score and environmental variables were simultaneously determined by RDA, and correlation and co-variations between species and environmental variables in biochar treated soils visually determined from ordination bi-plots of the data. The ordination of the main matrix (absolute species abundance) was constrained by a multiple regression on environmental variables in the second matrix (environmental variables). The resulting ordination diagram showed the treatments, species and environmental variables including name. The distance in the resulting ordination directs the maximum dissimilarity in species and length is relative to the rate of change. Microbial communities and chemical variables near the borders of RDA plot are most important in explaining the community variation in treatments, while the microbial communities and chemical variables near the center are of lesser importance. The distance in the same directions with similar magnitude are interpreted as correlating well with each other and the length of distance show more confidence in correlation (ter Braak, 1989;
Ter Braak and Prentice, 1988). The magnitude and angle between gradients indicate the strength and degree of correlation with an ordination axis or another gradient. The vector indicates the direction in which the treatment score would move if the value of variable increased.

\section{Results and Discussions}

\subsection{Elemental analysis of soils and biochars}

The total elemental concentrations in the Psammaquent, Plinthudult and biochars were measured by ICP Mass Spectrometry (Table 1). The Plinthudult contained higher concentrations of $\mathrm{K}$, $\mathrm{Ca}, \mathrm{Na}, \mathrm{Mg}, \mathrm{As}, \mathrm{Ni}, \mathrm{Pb}, \mathrm{Cd}, \mathrm{Fe}, \mathrm{B}, \mathrm{Mo}, \mathrm{Zn}, \mathrm{Cu}, \mathrm{Cr}$ and $\mathrm{Al}$ compared to the Psammaquent. The swine manure biochar contained higher concentration of $\mathrm{Al}, \mathrm{Mg}, \mathrm{Ca}, \mathrm{Fe}, \mathrm{Mo}, \mathrm{Cu}, \mathrm{Zn}, \mathrm{Cd}, \mathrm{Pb}, \mathrm{Ni}$ and As than the other biochars. The $P$. australis biochar contained higher concentration of $\mathrm{Cr}$ followed by $B$. rapa, swine manure and fruit peel biochars. The $B$. rapa and fruit peel biochars contained higher content of $\mathrm{B}, \mathrm{Na}$ and $\mathrm{K}$ compared to the others. The B. rapa and fruit peel biochars contained high $\mathrm{pH}$ followed by swine manure and $P$. australis biochars.

Table 1. Total elemental concentrations and $\mathrm{pH}$ of biochars and soils used in experiment $\left(\mathrm{mg} \mathrm{kg}^{-1}\right)$

\begin{tabular}{|c|c|c|c|c|c|c|c|c|c|c|c|c|c|c|c|c|c|}
\hline & $\mathrm{pH}$ & K & $\mathrm{Ca}$ & $\mathrm{Na}$ & $\mathrm{Mg}$ & $\mathrm{Al}$ & $\mathrm{Cr}$ & $\mathrm{Cu}$ & $\mathrm{Zn}$ & $\mathrm{Cd}$ & $\mathrm{Pb}$ & $\mathrm{Ni}$ & As & Mn & $\mathrm{Fe}$ & B & Mo \\
\hline $\mathrm{PA}$ & $\begin{array}{l}8.4 \pm 0 \\
.9\end{array}$ & $5895 \pm 73$ & $\begin{array}{l}1203 \\
\pm 13\end{array}$ & $\begin{array}{l}356.9 \pm \\
4\end{array}$ & $546.3 \pm 6$ & $\begin{array}{l}430.6 \pm 4 \\
8\end{array}$ & $64.6 \pm 0.7$ & $9.5 \pm 0.1$ & $\begin{array}{l}62.6 \pm 0 . \\
7\end{array}$ & $\begin{array}{l}0.3 \pm \\
0\end{array}$ & $5.2 \pm 0.1$ & $\begin{array}{l}17.9 \pm 0 . \\
2\end{array}$ & $\begin{array}{l}14.7 \pm 0 . \\
2\end{array}$ & $\begin{array}{l}170.6 \pm 1 . \\
9\end{array}$ & $\begin{array}{l}578.9 \pm 6 . \\
5\end{array}$ & $4.3 \pm 0.1$ & $0.8 \pm 0.0$ \\
\hline BR & $\begin{array}{l}10.0 \pm \\
0.6\end{array}$ & $\begin{array}{l}54084 \pm 9 \\
9\end{array}$ & $\begin{array}{l}13294 \\
\pm 96\end{array}$ & $\begin{array}{l}5832 \pm 8 \\
6\end{array}$ & $1966 \pm 29$ & $210 \pm 3.1$ & $38.0 \pm 0.6$ & $9.7 \pm 0.1$ & $\begin{array}{l}30.9 \pm 0 . \\
5\end{array}$ & $\begin{array}{l}0.4 \\
\pm 0\end{array}$ & $2.4 \pm 0.1$ & $\begin{array}{l}10.3 \pm 0 . \\
2\end{array}$ & $\begin{array}{l}25.4 \pm 0 \\
4\end{array}$ & $55.2 \pm 0.8$ & $\begin{array}{l}446.7 \pm 6 . \\
6\end{array}$ & $\begin{array}{l}42.6 \pm 0 . \\
6\end{array}$ & $2.7 \pm 0.0$ \\
\hline SM & $\begin{array}{l}9.6 \pm 0 \\
.8\end{array}$ & $\begin{array}{l}19842 \pm 9 \\
3\end{array}$ & $\begin{array}{l}23241 \pm 4 \\
3\end{array}$ & $\begin{array}{l}5196 \pm 7 \\
6\end{array}$ & $\begin{array}{l}11099 \pm 6 \\
4\end{array}$ & $5168 \pm 76$ & $27.4 \pm 0.4$ & $\begin{array}{l}1692 \pm 2 \\
5\end{array}$ & $\begin{array}{l}1543 \pm 2 \\
3\end{array}$ & $\begin{array}{l}1.0 \\
\pm 0\end{array}$ & $\begin{array}{l}42.2 \pm 0 . \\
6\end{array}$ & $\begin{array}{l}17.0 \pm 0 . \\
3\end{array}$ & $\begin{array}{l}46.2 \pm 0 \\
7\end{array}$ & $657 \pm 9.7$ & $\begin{array}{l}3584 \pm 2 \text {. } \\
9\end{array}$ & $\begin{array}{l}32.2 \pm 0 . \\
5\end{array}$ & $\begin{array}{l}10.5 \pm 0 . \\
1\end{array}$ \\
\hline FP & $\begin{array}{l}10.3 \pm \\
0.4\end{array}$ & $\begin{array}{l}28476 \pm 4 \\
5\end{array}$ & $\begin{array}{l}4730.2 \\
\pm 70\end{array}$ & $\begin{array}{l}1018 \\
\pm 15\end{array}$ & $3603 \pm 53$ & $610 \pm 9.0$ & $22.5 \pm 0.3$ & $\begin{array}{l}23.1 \pm 0 . \\
3\end{array}$ & $\begin{array}{l}48.4 \pm 0 . \\
7\end{array}$ & $\begin{array}{l}0.2 \\
\pm 0\end{array}$ & $5.1 \pm 0.1$ & $\begin{array}{l}12.9 \pm 0 . \\
2\end{array}$ & $\begin{array}{l}24.8 \pm 0 \text {. } \\
4\end{array}$ & $\begin{array}{l}1384 \pm 0 . \\
5\end{array}$ & $\begin{array}{l}488.5 \pm 7 \text {. } \\
2\end{array}$ & $\begin{array}{l}36.8 \pm 0 . \\
5\end{array}$ & $0.6 \pm 0.0$ \\
\hline Pl & $\begin{array}{l}5.2 \pm 0 \\
.6\end{array}$ & $\begin{array}{l}6913.9 \pm \\
41\end{array}$ & $\begin{array}{l}798.05 \pm \\
51\end{array}$ & $649 \pm 41$ & $1206 \pm 76$ & $3612 \pm 31$ & $37.3 \pm 2.4$ & $\begin{array}{l}27.3 \pm 1 . \\
7\end{array}$ & $\begin{array}{l}59.3 \pm 3 \\
8\end{array}$ & $\begin{array}{l}0.7 \pm \\
0\end{array}$ & $\begin{array}{l}40.4 \pm 2 . \\
6\end{array}$ & $\begin{array}{l}21.5 \pm 1 . \\
4\end{array}$ & $\begin{array}{l}36.7 \pm 2 \text {. } \\
3\end{array}$ & $97.5 \pm 6.2$ & $\begin{array}{l}9779.3 \pm \\
23\end{array}$ & $\begin{array}{l}94.6 \pm 6 . \\
0\end{array}$ & $1.6 \pm 0.1$ \\
\hline Ps & $\begin{array}{l}4.5 \pm 0 \\
.5\end{array}$ & $\begin{array}{l}7250.3 \pm \\
62\end{array}$ & $\begin{array}{l}235.2 \pm 1 \\
5\end{array}$ & $\begin{array}{l}1105 \pm 7 \\
0\end{array}$ & $954 \pm 60$ & $3525 \pm 25$ & $\begin{array}{l}16.3 \pm 1.0 \\
4\end{array}$ & $8.9 \pm 0.6$ & $\begin{array}{l}28.8 \pm 1 . \\
8\end{array}$ & $\begin{array}{l}0.2 \pm \\
0\end{array}$ & $\begin{array}{l}21.8 \pm 1 . \\
4\end{array}$ & $8.6 \pm 0.6$ & $\begin{array}{l}24.9 \pm 1 . \\
6\end{array}$ & $\begin{array}{l}103.2 \pm 6 . \\
6\end{array}$ & $\begin{array}{l}5111.7 \pm \\
26\end{array}$ & $\begin{array}{l}28.2 \pm 1 . \\
8\end{array}$ & $0.7 \pm 0.0$ \\
\hline
\end{tabular}

PA (Phragmites australis), BR (Brassica rapa), SM (Swine manure), FP (Fruit peels), Pl (Plinthudult), Ps (Psammaquent) 


\subsection{Biochars influence the available elemental concentrations in soils}

\subsubsection{Psammaquent}

The available elemental concentrations in Psammaquent amended with 4 biochar types at two application rates were measured by ICP mass after 180 days (Table 2). Biochar types with 2 application rates significantly changed the available elemental concentrations in a Psammaquent. The swine manure $3 \%$ biochar treatment contained significantly higher available concentration of $\mathrm{Na}, \mathrm{Mg}, \mathrm{Ca}, \mathrm{Fe}, \mathrm{Cu}$, $\mathrm{Zn}, \mathrm{As}$ and $\mathrm{Mo}$ and in contrast $\mathrm{Pb}, \mathrm{Cd}$ and $\mathrm{Al}$ were reduced compared to other biochar treatments to Psammaquent and control soil. Swine manure biochar contained higher concentration of $\mathrm{Na}, \mathrm{Mg}, \mathrm{Ca}, \mathrm{Fe}$, $\mathrm{Cu}, \mathrm{Zn}, \mathrm{As}$ and $\mathrm{Mo}$, therefore biochar addition to Psammaquent increased the available concentration of elements in soil. In addition, swine manure biochar had less surface area that can adsorb less elements on its surfaces, consequently available elemental concentration increased in swine manure biochar treated Psammaquent than the control. The $P$. australis biochar treatments (1 and $3 \%$ ) significantly increased the available elemental concentrations of $\mathrm{Na}, \mathrm{Mg}, \mathrm{K}$, $\mathrm{Ca}, \mathrm{Al}, \mathrm{Fe}, \mathrm{Mo}$ and $\mathrm{B}$ in Psammaquent compared to the control. The $\mathrm{Al}$ and $\mathrm{B}$ in $3 \%$ P. australis biochar treatment to Psammaquent contained highest available concentrations among all biochar treatments and control soil. The available concentrations of $\mathrm{Pb}, \mathrm{Cd}$, $\mathrm{Zn}, \mathrm{Cu}$ and $\mathrm{Ni}$ were significantly reduced in P.australis biochar treatments as compared to the control soil. The higher application rate of $P$. australis biochar (3\%) pertained higher alleviation and reduction rates in availability of elemental concentrations than $1 \%$ biochar treatment to Psammaquent. It reveals that biochars with low elemental concentrations and higher surface area can adsorb more elements on surfaces. Therefore, biochars reduced the availability and leaching of elements and nutrients from soil to environment. The B. rapa biochar treatments (1 and $3 \%)$ to Psammaquent also significantly increased the available concentrations of $\mathrm{Na}, \mathrm{K}, \mathrm{Mn}, \mathrm{B}$ and $\mathrm{Pb}$ as compared to the control. In contrast the available concentrations of $\mathrm{Mg}, \mathrm{Al}, \mathrm{Fe}, \mathrm{Ni}, \mathrm{Cu}, \mathrm{Zn}$ and $\mathrm{Cd}$ were significantly reduced in $B$. rapa biochar treatments to Psammaquent. The decrease or increase in availability of elements was higher in $3 \%$ application rate of $B$. rapa biochar to Psammaquent. The B. rapa biochar addition to Psammaquent decreased the available concentration of toxic elements. It may be due to the increased $\mathrm{pH}$ in soil and higher surface area of biochar, which facilitate the fixation of elements in soils and reduce their release to the environment. Furthermore, higher application rate of $B$. rapa biochars to Psammaquent can improve soil fertility. The fruit peel biochar treatments to Psammaquent significantly increased the available concentrations of $\mathrm{Na}, \mathrm{Mg}, \mathrm{K}$, $\mathrm{Ca}, \mathrm{Mn}, \mathrm{Fe}$, and $\mathrm{B}$ and decreased the $\mathrm{Ni}, \mathrm{Cu}, \mathrm{Zn}, \mathrm{Cd}$ and $\mathrm{Pb}$ compared to the control soil. Results revealed that fruit peel biochar is the most suitable biochar for Psammaquent because it increased the available concentrations of nutrients and reduced the potentially toxic elements. Fruit peel biochar can improve the Psammaquent quality, and consequently increase plant growth and yield coupled with additional environmental benefits such as $\mathrm{C}$ sequestration for longer time. However, biochars from P. australus, B. rapa and fruit peel increased the concentration of nutrients in soils, which are beneficial for growing plants. The biochars containing higher concentration of toxic elements can affect the plant growth through some unknown biological functions and their uptake by plants is also higher in acidic soils. The normal range of $\mathrm{Cd}$ in soil is from 0.2 to $0.4 \mathrm{mg} \mathrm{kg}^{-1}$ (Haigh, 1995), however, the increases of $\mathrm{Cd}$ in biochar treated soils would cause severe toxicity to plants. 
Table 2. Available elemental concentrations $\left(\mathrm{mg} \mathrm{kg}^{-1}\right)$ in biochar amended Plinthudult and Psammaquent.

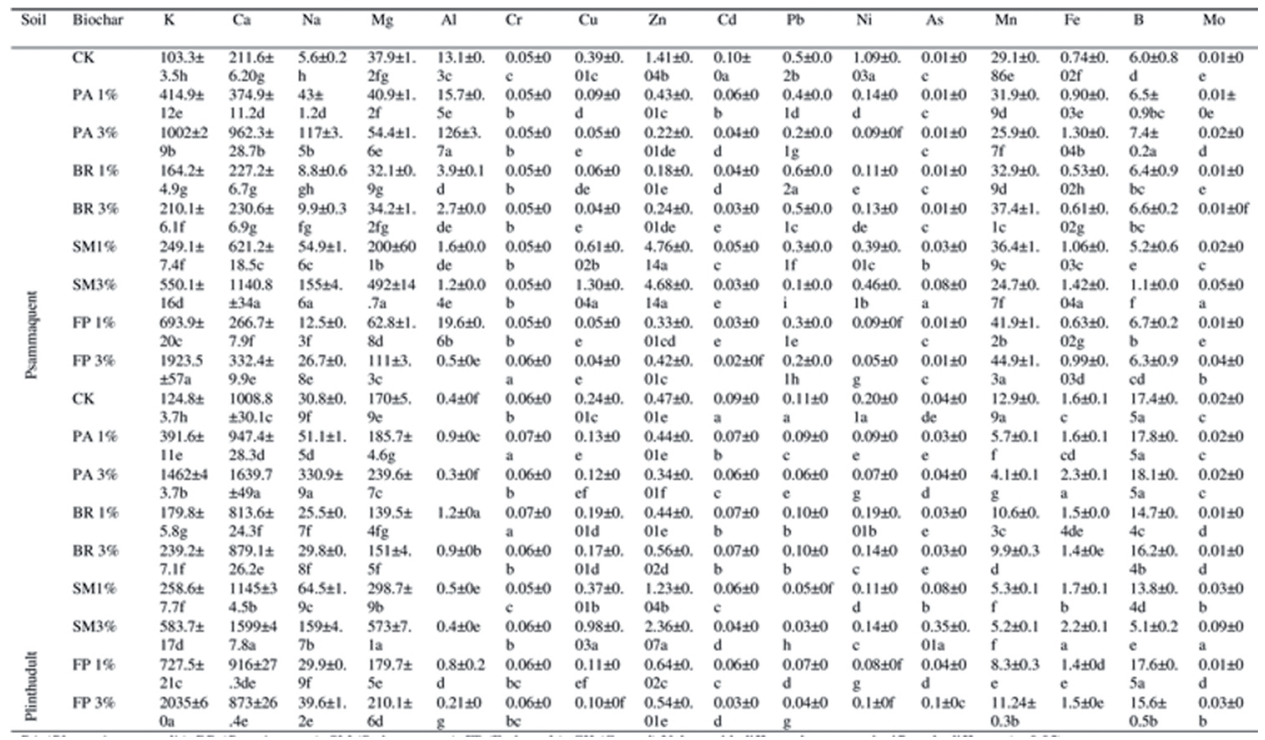

PA (Phragmites australis), BR (Brassica rapa), SM (Swine manure), FP (Fruit peels), CK (Control)

Values with different letters are significantly different $(p<0.05)$

\subsubsection{Plinthudult}

The available elemental concentrations in biochar amended Plinthudult were measured after 180 days. Biochar type and application rates (1 and $3 \%$ ) significantly changed the available concentration of elements in Plinthudult (Table 2). The P. australis biochar significantly increased the available concentration of $\mathrm{Na}, \mathrm{Mg}, \mathrm{K}, \mathrm{Ca}$ and $\mathrm{Fe}$, and reduced that of $\mathrm{Mn}, \mathrm{Ni}, \mathrm{Cu}, \mathrm{Zn}, \mathrm{Cd}$ and $\mathrm{Pb}$ in Plinthudult compared to the control. The increased available elemental concentrations resulted from higher concentration of nutrients in biochar. In addition, the biochar significantly reduced the availability of potentially toxic elements by changing soil properties, elemental fixation and surface adsorption. It reveals that $P$. australis biochars can improve soil quality and productivity in Plinthudult. The B.rapa biochar application rates significantly increased the available elemental concentration of $\mathrm{K}$ and $\mathrm{Zn}$ in Plinthudult as compared to the control. The available concentrations of $\mathrm{Mg}, \mathrm{Ca}, \mathrm{Mn}, \mathrm{Fe}, \mathrm{Ni}, \mathrm{Cu}, \mathrm{As}, \mathrm{Mo}, \mathrm{Cd}, \mathrm{B}$ and $\mathrm{Pb}$ were significantly decreased in B. rapa biochar added Plinthudult than the control soil. The decrease in available concentrations of elements in B. rapa biochar added Plinthudult has been credited to the changed soil properties, which influenced the elemental dynamics by fixation and adsorption on biochar surfaces. These fixed elements in Plinthudult due to B. rapa biochar can't release to the environment, consequently these elements might be easily available for growing plants. The swine manure biochar additions significantly increased the available concentrations of $\mathrm{Na}, \mathrm{Mg}, \mathrm{K}$, $\mathrm{Ca}, \mathrm{Fe}, \mathrm{Cu}, \mathrm{Zn}$, As and $\mathrm{Mo}$ and decreased the $\mathrm{Mn}$, $\mathrm{Ni}, \mathrm{Cd}, \mathrm{B}$ and $\mathrm{Pb}$ in Plinthudult as compared to the control soil. The swine manure biochar $3 \%$ treatment contained the highest available concentrations of $\mathrm{Mg}, \mathrm{Ca}, \mathrm{Fe}, \mathrm{Cu}, \mathrm{Zn}$, As and Mo among all biochar 
treatments and control soil and it has been credited to the higher concentration of elements in swine manure biochar. It suggests that higher application rate of swine manure biochar can cause harmful effects on plant growth and other soil biota. The fruit peel biochar types and application rates also significantly increased the available concentrations of $\mathrm{Na}, \mathrm{Mg}, \mathrm{K}$ and $\mathrm{Zn}$ and reduced the $\mathrm{Al}, \mathrm{Ca}, \mathrm{Mn}, \mathrm{Fe}, \mathrm{Ni}, \mathrm{Cu}, \mathrm{Cd}$, $\mathrm{B}$ and $\mathrm{Pb}$ in Plinthudult as compare to the control soil. It reveals that fruit peel biochar reduced the available concentration of potentially toxic elements in Plinthudult through fixation and adsorption. It can reduce the release of elements to environment and increases nutrient concentration in soil consequently it can improve the crop yield in biochar added soils.

\subsection{Microbial community structure in biochar amended soils}

\subsubsection{Psammaquent}

The sum of PLFA markers (mol \%), indicating different microbial groups identified in biochar treated Psammaquent and control soil was measured (Table 3). The bacterial PLFA markers were significantly changed with biochar types and treatment rates to the soil. The bacterial PLFAs in fruit peels, swine manure and $P$. australis $1 \%$ biochar treatments contained significantly higher concentrations as compared to the other biochars and control soil. For this reason, Psammaquent is nutritionally poor and biochar addition provides further substrate for microbial utilization, therefore, bacterial PLFA concentrations were increased in biochar added Psammaquent as compared to the control soil. The fungal PLFA concentrations were significantly increased in all biochar treatments and it was higher in B. rapa $3 \%$ biochar as compared to the control and others. The B. rapa at harvesting stage contains higher amount of cellulose, which is a suitable substrate for fungi, therefore, fungal
PLFA concentrations were increased as compared to other biochar treatments and control soil. The fungal: bacterial PLFA ratio was significantly reduced in all biochar treatments than the control soil and the lowest value was found in fruit peel biochar $3 \%$ treatment. The PLFAs indicating soil actinomycetes were significantly changed with biochar types and treatments to the Psammaquent, whereas, the swine manure biochar $3 \%$ contained the highest concentrations among all biochar treatments and control soil. The G-ve bacterial PLFAs were significantly increased in all biochar treatments as compared to the control. The $3 \%$ fruit peel biochar contained the highest concentration of G-ve PLFAs among all biochar treatments and the control soil. Fruit peels contain higher amount of nutrients and are considered a suitable substrate for $\mathrm{G}$-ve bacteria, therefore, this biochar treatment significantly increased the G-ve PLFA concentrations in Psammaquent. However, the PLFA markers, indicating the $\mathrm{G}+\mathrm{ve}$ bacterial population were considerably $(\mathrm{p}<0.05)$ reduced in all biochar treatments as compared to the control soil. The anteiso PLFA concentrations were significantly reduced in all biochar treatments than the control soil except $3 \%$ fruit peels biochar treatment. The iso: anteiso ratios are an indicator of environmental stress (Wu et al., 2009a), and significantly reduced $(\mathrm{p}<0.05)$ in all biochar treatments as compared to the control soil and $3 \% \mathrm{~B}$. rapa biochar treatment. Again it indicates that biochars reduced the stress in microbial communities of nutritionally poor soils. The concentrations of saturated PLFAs also were reduced $(\mathrm{p}<0.05)$ in all biochar treatments compared to the control soil, while $3 \%$ swine manure biochar treatment contained similar concentrations to the control soil. Sulfate reducing bacterial PLFAs were significantly reduced $(\mathrm{p}<0.05)$ in the P. australis, B. rapa and fruit peel biochar treatments to the Psammaquent but increased in $3 \%$ swine manure biochar as compared to the control and other biochar treatments. Sulfate reducers are an indicator of extreme environment and their higher 
concentration in swine manure biochar treatment might be due to the higher available element concentrations. The concentrations of PLFA markers representing the anaerobic microbial population significantly increased in all biochar treatments as compared to the control soil. However, $3 \%$ swine manure biochar contained the highest concentration of anaerobic microbial PLFAs, among all biochar treatments and control soil (Table 3). The Psammaquent contain higher sand content and less density, in contrast swine manure biochar have smaller particle and pore size, upon addition to soil (3\%) it reduces the soil density and generates anaerobic environment, which facilitates the anaerobic bacterial growth. However, The PCA analysis in biochar treated Psammaquent (Table 5) showed that fungi $(\mathrm{r}=0.96)$, actinobacteria $(\mathrm{r}=0.83)$, protozoa $(\mathrm{r}=0.96)$, cyclopropane $(\mathrm{r}=0.97$, anteiso $(\mathrm{r}=0.97)$, sulfate reducers $(\mathrm{r}=0.98)$, anaerobic bacteria $(\mathrm{r}=0.99)$ and Mo:Cy ratio $(\mathrm{r}=0.90)$ were the most positively loading factors on PCA1. The bacteria $(\mathrm{r}=-0.98), \mathrm{G}+\mathrm{ve}(\mathrm{r}=-0.98)$, iso $(\mathrm{r}=-0.93)$ and saturated PLFAs $(\mathrm{r}=-0.91)$ were the most negatively loading factors for PCA1. The G-ve $(r=0.90)$ and monosaturated PLFAs $(\mathrm{r}=0.72)$ positively and iso: anteiso $(\mathrm{r}=-0.93)$ were the negatively loading factors for PCA 2 (Table 5). Furthermore, the changes in microbial communities and available element concentrations in biochar added Psammaquent were analyzed by RDA to explain the correlation and covariation between PLFA concentrations and available elements within biochar types and treatments. The RDA cumulatively explained $77 \%$ correlation and covariation among microbial communities and available elements in different biochar treatments. The RDA 1 and 2 explained 51 and $27 \%$ correlation and covariation among biochar type, treatments, available elemental concentrations and microbial communities in Psammaquent, respectively (Figure 1 a).

Table 3. PLFA concentrations indicating different microbial groups (mol \%) in biochar amended Psammaquent and Plinthudult

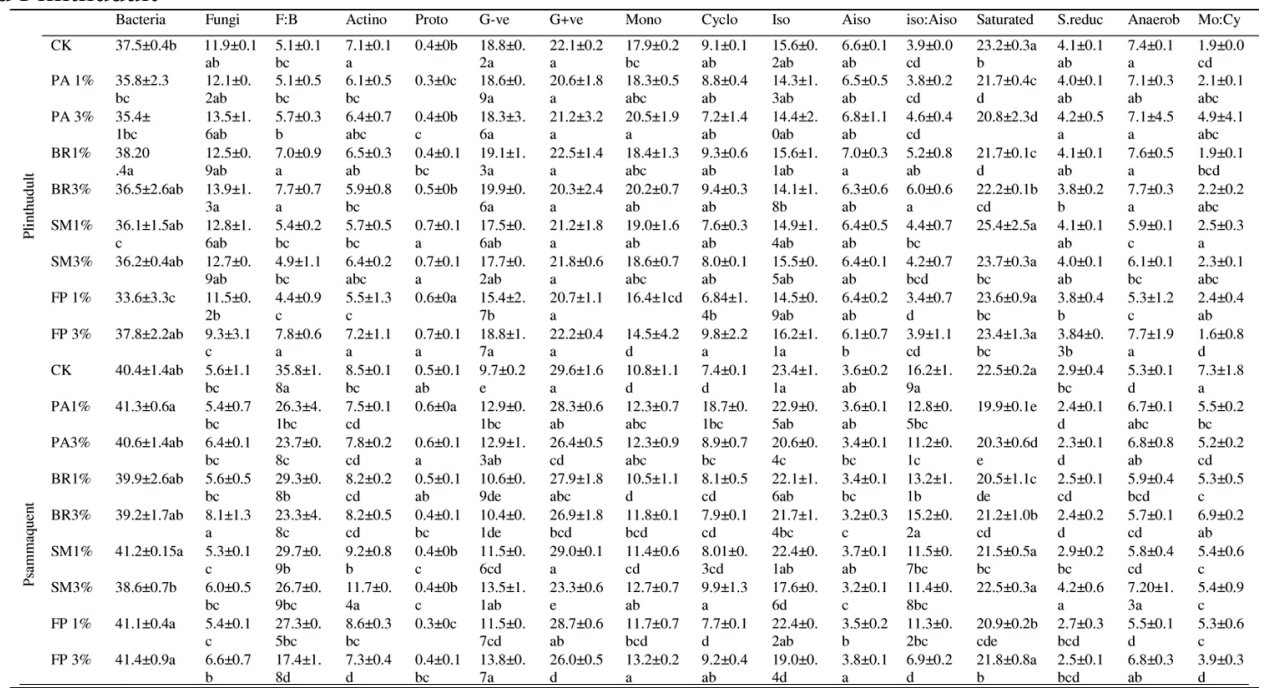

F:B (fungal bacterial ratio), Actino (actinomycete), G-ve (Gram negative bacteria), G+ve (Gram positive bacteria), Mono (Monosaturated PLFAs), Cyclo (Cyclopropane), Iso (iso PLFAs), anteiso (anteiso PLFAs), iso:anteiso (iso and anteiso PLFA ratio), S. reduce (sulfate reducers), Mo: Cy (monosaturated and cyclopropane PLFA ratio), PA (Phragmites australis), BR (Brassica rapa), SM (Swine manure), FP (Fruit peels), CK (Control). Values with different letters are significantly different $(\mathrm{p}<0.05)$ 
Table 5. Component analyses in biochar treated Plinthudult and Psammaquent

\begin{tabular}{|c|c|c|c|c|}
\hline \multirow[t]{2}{*}{ Representative } & \multicolumn{2}{|c|}{ Plinthudult } & \multicolumn{2}{|c|}{ Psammaquent } \\
\hline & $\mathrm{PCl}$ & PC 2 & $\mathrm{PC} 1$ & PC2 \\
\hline Bacteria & 0.89 & 0.35 & -0.98 & 0.18 \\
\hline Fungi & -0.55 & 0.69 & 0.96 & -0.14 \\
\hline $\mathrm{F}: \mathrm{B}$ & 0.68 & 0.36 & -0.39 & 0.33 \\
\hline Actino & 0.79 & 0.08 & 0.83 & -0.05 \\
\hline protozoa & 0.08 & -0.77 & 0.96 & -0.18 \\
\hline G-ve & 0.62 & 0.72 & 0.42 & 0.89 \\
\hline $\mathrm{G}+\mathrm{ve}$ & 0.65 & -0.06 & -0.98 & -0.11 \\
\hline Mono & -0.50 & 0.78 & 0.65 & 0.67 \\
\hline Cyclo & 0.91 & 0.26 & 0.97 & 0.19 \\
\hline ISO & 0.77 & -0.27 & -0.93 & -0.32 \\
\hline Anteiso & -0.22 & 0.59 & 0.97 & -0.15 \\
\hline Iso:Anteiso & 0.13 & 0.77 & -0.029 & -0.93 \\
\hline Saturated s & 0.08 & -0.72 & -0.91 & 0.17 \\
\hline S. reduce & -0.15 & 0.53 & 0.98 & -0.13 \\
\hline Anaerobic & 0.86 & 0.25 & 0.99 & 0.05 \\
\hline Mo:Cy & -0.67 & 0.38 & 0.89 & -0.45 \\
\hline
\end{tabular}

F:B (fungal bacterial ratio), Actino (actinomycete), G-ve (Gram negative bacteria), G+ve (Gram positive bacteria), Mono (Monosaturated PLFAs), Cyclo (Cyclopropane), Iso (iso PLFAs), anteiso (anteiso PLFAs), iso:anteiso (iso and anteiso PLFA ratio), S.reduce (sulfate reducers), Mo:Cy (monosaturated and cyclopropane PLFA ratio)

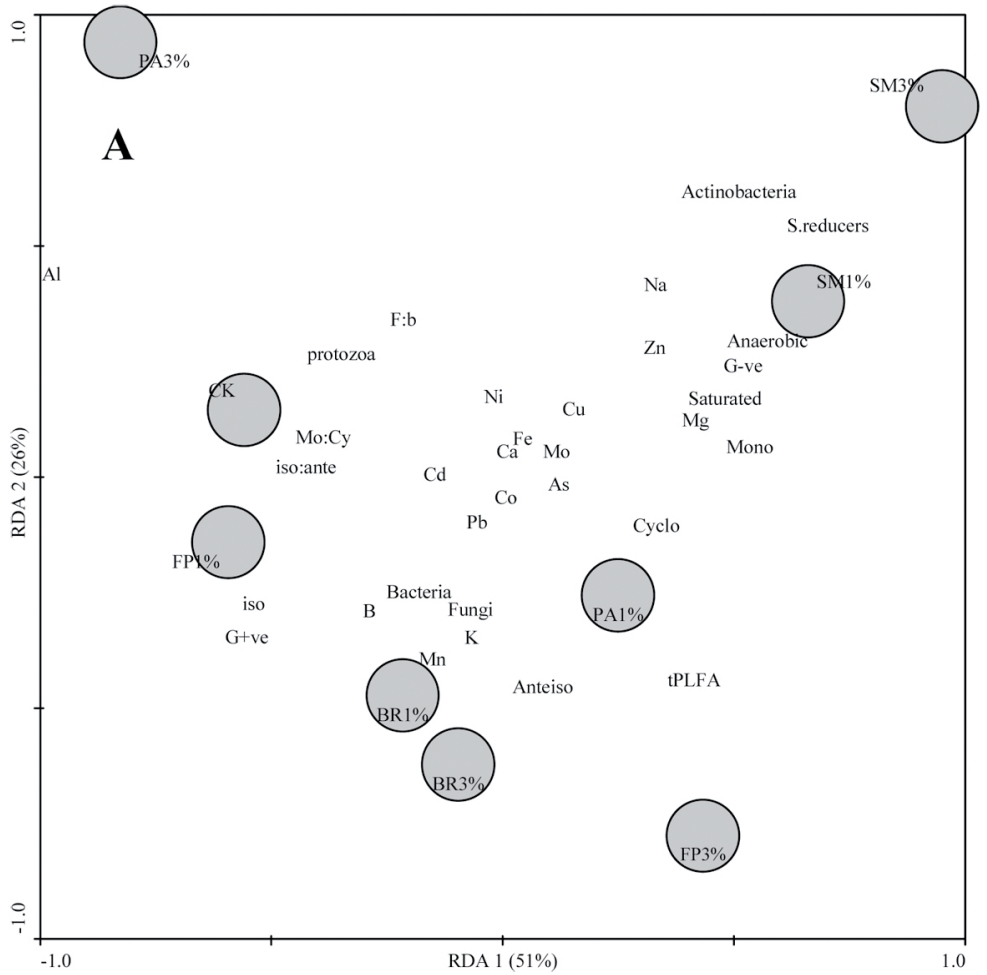

Figure 1a. Redundancy analysis of microbial communities ( $\Sigma$ indicator PLFAs) available elements and biochar treatments in (a) Psammaquent and (b) Plinthudult Where, I:A (iso:anteiso), F:B (fungi:bacteria), Cy:Mo (cyclopropane:monosaturated), S. reducers (sulfate reducers), PLFAt (Total PLFAs), G+ve (Gram positive bacteria), G-ve (Gram negative bacteria), Iso (iso PLFAs). 


\subsubsection{Plinthudult}

Least square differences at $\mathrm{P}=0.05$ PLFA markers (mol $\%$ ), representing different microbial communities, in biochar treatments to the Plinthudult were calculated (Table 3). The bacterial PLFAs were increased in $B$. rapa $1 \%(\mathrm{p}<0.05)$ biochar treatment compared to the others and control soils. The $P$. australis, swine manure and fruit peel $1 \%$ biochar treatments to the Plinthudult caused a major decrease in the bacterial PLFA concentrations as compared to those in the control soil. It has been credited to the changed soil properties and substrates due to biochars. These properties affect the existing bacterial population as a result gradually new bacterial population adopts according the available nutrients and soil environment. The fungal PLFA markers were significantly increased $(\mathrm{p}<0.05)$ in $B$. rapa $3 \%$ and decreased in fruit peel biochar as compared to the control and other biochar treatments to Plinthudult. The B. rapa contain higher amount of cellulose at mature stage as compared to fruit peels and it is a suitable substrate for fungi, therefore $B$. rapa biochar $3 \%$ treatment contained higher concentration of fungal PLFAs in this soil. The fungal:bacterial PLFA ratio was higher in B. rapa, and fruit peel biochar 3 $\%$, but reduced in fruit peel biochar $1 \%$ treatment to the soil. The actinomycete PLFAs were significantly higher in control and fruit peel biochar $3 \%$ as compared to other biochar treatments to Plinthudult. The protozoal PLFAs were significantly increased in swine manure and fruit peel biochar treatments than the control and other biochar treatments. The protozoa are more resistant to environmental changes than bacteria therefore, protozoal PLFA concentration increased in biochar treated Plinthudult. The monosaturated PLFAs were much higher in $P$. australis, B. rapa and swine manure biochar treated Plinthudult while there were considerable decreases in fruit peel biochar as compared to the control and other biochar treatments. There were no significant changes in cyclopropane PLFA concentrations in P. australis, B. rapa and swine manure biochar treatments but these were statistically significant in fruit peels biochar as compared to the control and other treatments. The iso PLFA concentration was not changed in most biochar treatments except fruit peel biochar $3 \%$ treatment, which contained significantly higher values. The $B$. rapa biochar contained significantly lower concentrations of iso PLFAs compared to the control and other biochar treatments to the Plinthudult. The B. rapa biochar treatment contained significantly higher concentration of anteiso PLFAs, while no significant changes were observed in other biochar treatments compared to the control soil. The iso:anteiso PLFA ratio is normally used as an environmental stress indicator (Pettersson and Baath, 2003). It was significantly greater in all biochar treatments than the control and the highest concentration was measured in B. rapa biochar $3 \%$ treatment. It indicates that changes in soil properties due to biochar exerts stress on microbial communities in Plinthudult, gradually it leads to the adaptation or change in soil microbial communities. The saturated PLFA concentrations were notably changed in all biochar treated Plinthudult. However it was decreased in P. australis and B. rapa and increased in the swine manure and fruit peel biochar treatments compared to the control and other biochar treatments. The PLFA concentrations derived from the sulfate reducers were also markedly increased with biochar type and application rate. These were significantly increased in $P$. australis biochar treatment and decreased in fruit peel and B. rapa biochar (Table 3) as compared to the control and other biochar treatments. The anaerobic microbial PLFAs were significantly reduced in the swine manure and fruit peels $1 \%$ biochar treatments compared to the control and other biochar treatments. 
It may be due to the lesser hollow structures in these biochars compared to others. The hollow structures of biochars generate anaerobic environment due to filling of soil solution that can facilitate the anaerobic bacterial growth. The ratio between monosaturated and cyclopropane (mo:cy) PLFA markers indicating nutritional stress were significantly increased in $P$. australis, B. rapa and swine manure biochar treatments to the Plinthudult, while this ratio was significantly reduced in the fruit peel $3 \%$ compared to the control and other biochar treatments. It reveals that biochars change the substrate for existing microbial population and caused nutritional stress in bacterial communities. However, biochars generated from different feedstocks contain different structures, mineral contents and substrates which are responsible for proliferation of specific bacterial populations in soils by providing specific substrates and habitats. Furthermore, The PLFA markers indicating different microbial groups were subjected to PCA and factor analyses to examine the changes in microbial community structure in the biochar treated Plinthudult. The cyclopropane $(\mathrm{r}=0.91)$, general bacterial $(\mathrm{r}=0.89)$, actinobacterial $(\mathrm{r}=0.79)$ iso $(\mathrm{r}=0.77)$ and anaerobic bacterial PLFAs ( $\mathrm{r}=0.86$ ) were the most positively loading factors (Table 5) on PCA1. The iso:anteiso ( $\mathrm{r}=0.77)$, monosaturated PLFAs $(\mathrm{r}=0.78)$ and $\mathrm{G}$-ve bacterial PLFAs ( $\mathrm{r}=0.72)$ were the most positively loading factors on PCA 2. The protozoa $(\mathrm{r}=-0.84)$ and saturated PLFAs $(\mathrm{r}=-0.72)$ were loaded negatively on PCA 2 (Table 5). The changes in microbial communities and available elemental concentration in biochar added Plinthudult were analyzed by RDA to explain the correlation and co-variation between PLFA concentrations and available elements within biochar types and treatments. The RDA explained cumulatively $80 \%$ correlation and co-variation among microbial communities and environmental gradients in different biochar treatments. The RDA 1 and 2 explained 47 and $33 \%$ correlation and co-variation, respectively among biochar type, treatments, available elemental concentrations and microbial communities in Plinthudult (Figure 1 b).

\subsection{Influence of available elements on microbial communities in biochar added soils}

Biochar addition to soils generally increases soil microbial biomass and changes microbial community structure and competition for available nutrients (Pietikäinen et al., 2000) by changing physicochemical properties of soils (Steiner et al., 2007). Bacteria and fungi are the primary decomposers of available soil organic matter and comprise $90 \%$ of the soil microbial biomass (Six et al., 1998). Alterations of soil properties by biochar addition have direct or indirect effect on fungi and other microbial communities (Verheijen et al., 2010). Our results indicated that different biochar types and application rates to different soils affected the microbial communities, also showed correlations with different available element concentrations in biochar amended soils. The bacterial PLFA concentrations changed within biochar type and application rate to both soils due to biochar based changes in available elemental concentrations. The higher available element concentrations (Table 2) due to biochar addition, induces toxic effects on bacterial population, because several elements are lethal to bacteria at higher levels (Preem et al., 2012; Shi et al., 2002). The fungal PLFAs were significantly increased in all biochar treatments to soils except fruit peels biochar. It indicates that fungi can grow at increased available elemental concentrations in soil as reported by Shi et al. (2002). The significant positive correlation of $\mathrm{G}+\mathrm{ve}$ bacterial PLFAs with $\mathrm{Ni}$ in the Plinthudult indicated that $\mathrm{G}+\mathrm{ve}$ bacteria can also grow at higher available concentrations of specific elements. The actinobacteria were decreased in all biochar treated soils except the swine manure biochar treatments to Psammaquent and it may be due to the increased available elemental concentrations or increased protozoal 
population exerting grazing pressure on bacteria. In Plinthudult, the concentrations of protozoal PLFAs were significantly increased with all biochar treatments, except P. australis biochar treatment (Table 3). Here, the positive correlations of protozoal PLFAs with $\mathrm{Mg}, \mathrm{Zn}$ and $\mathrm{As}$ (Table 4), indicated that the increased concentrations of available elements positively influenced the protozoal population in biochar amended Plinthudult. The possible reason might be the increased porosity of soils due to biochar which facilitate the protozoal population. The G-ve PLFAs were slightly decreased in biochar amended Plinthudult but significantly increased in the Psammaquent compared to the control soil (Table 3) and showed a significant positive correlation with $\mathrm{Na}, \mathrm{Mg}$, $\mathrm{K}, \mathrm{Ca}, \mathrm{Fe}$ and negatively with $\mathrm{Pb}$ in the Psammaquent. This indicates that increased concentrations of available elements due to biochar (Table 2) affected the growth of G-ve bacteria in soils. The G+ve PLFAs were not significantly changed in the Plinthudult but decreased in all biochar treatments to the Psammaquent (Table 3) and negatively correlated with $\mathrm{K}$ (Table 4). This indicates that increased concentrations of available $\mathrm{K}$ due to biochar (Table 2) suppressed the growth of G+ve bacteria in soils, as previously reported by Preem et al. (2012). Higher concentrations of monosaturated PLFAs in biochar treatments rather than control and their positive correlations with $\mathrm{Na}, \mathrm{K}$ and $\mathrm{Ca}$ in the Psammaquent indicated that higher concentration of available elements increased the concentrations of monosaturated PLFAs in microbial communities of biochar amended soil. The anteiso PLFAs showed negligible differences between biochar treatments to the soils. This could be related to the, generally, low nutritional and the high exposure of microbial communities in soils to the elements.

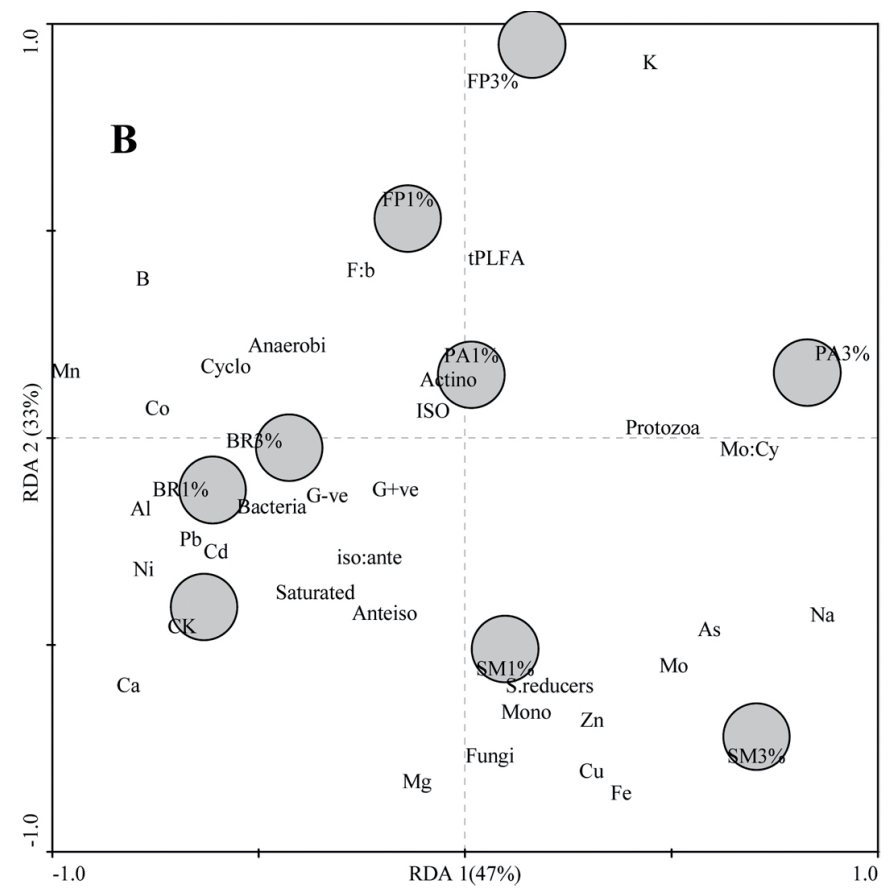

Figure 1b. Redundancy analysis of microbial communities ( $\Sigma$ indicator PLFAs) available elements and biochar treatments in (a) Psammaquent and (b) Plinthudult Where, I:A (iso:anteiso), F:B (fungi:bacteria), Cy:Mo (cyclopropane:monosaturated), S. reducers (sulfate reducers), PLFAt (Total PLFAs), G+ve (Gram positive bacteria), G-ve (Gram negative bacteria), Iso (iso PLFAs). 
The iso: anteiso ratios were significantly increased in the Plinthudult and decreased in the Psammaquent following biochar addition. This ratio had a significant negative correlation with $\mathrm{Na}, \mathrm{Mg}, \mathrm{K}$ and $\mathrm{Ca}$ in biochar amended Psammaquent. This indicates that the higher concentrations of available elements after biochar addition to soils reduced stress to the soil microbial communities in Psammaquent. However these were already stressed as indicated by higher iso: anteiso ratios in the control soil. The iso: anteiso ratios decreased in the biochar treatments due to physico-chemical changes in soils. The monosaturated: cyclopropane (Mo:Cy) is an indicators of environmental stress were higher within biochar treated Plinthudult. This indicates that increased concentrations of available elements and induced ntration substrate due to biochars caused nutritional stress in soil microbial communities. The reduced ratio of Mo:Cy in biochar treated Psammaquent compared to the control soil, showing that biochars facilitate microbial growth and their activities by changing, nutrient source, increased porosity, water holding capacity and sorption capacity of biochars in soils as discussed Jindo et al. (2012). The positive and negative correlations of PLFA with different available elements in biochar amended soils indicated that changed available element concentrations in soils also influence the microbial communities in different soils. The abundance of specific microbial communities in natural soils containing higher concentration of different elements has been also reported previously (Liang et al., 2012).

Table 4. Spearman's correlation coefficient among available elemental concentration and biomarkers in biochar treated Plinthudult and Psammaquent

\begin{tabular}{|c|c|c|c|c|c|c|c|c|c|c|c|c|c|c|c|c|}
\hline & $P_{s}$ & K & $\mathrm{Ca}$ & $\mathrm{Na}$ & $\mathrm{Mg}$ & Al & $\mathrm{Cu}$ & $\mathrm{Zn}$ & $\mathrm{Cd}$ & $\mathrm{Pb}$ & $\mathrm{Ni}$ & As & $\mathrm{Mn}$ & $\mathrm{Fe}$ & B & Mo \\
\hline \multirow{17}{*}{ 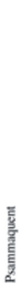 } & Bacteria & 0.47 & 0.10 & 0.10 & 0.25 & -0.21 & 0.29 & 0.20 & 0.21 & -0.19 & -0.33 & -0.55 & 0.50 & 0.10 & 0.09 & -0.55 \\
\hline & Fungi & 0.23 & .004 & .004 & .0 .10 & .007 & .045 & -0.43 & -0.47 & .005 & -0.17 & 0.14 & 0.10 & 0.08 & 0.18 & 0.14 \\
\hline & $\mathrm{F}: \mathrm{b}$ & $-0.65^{\circ}$ & .0 .30 & .0 .30 & .0 .07 & 0.30 & $0.66^{\circ}$ & 0.43 & 0.31 & 0.24 & $0.64^{*}$ & 0.00 & -0.28 & -0.18 & -0.39 & 0.00 \\
\hline & Actino & -0.31 & 0.16 & 0.16 & 0.39 & 0.06 & $0.64^{*}$ & 0.50 & -0.21 & -0.23 & $0.68^{*}$ & 0.55 & -0.29 & 0.16 & -0.47 & 0.55 \\
\hline & Protozoa & -0.19 & 0.03 & 0.03 & -0.45 & 0.25 & 0.07 & -0.23 & 0.55 & 0.24 & -0.08 & -0.22 & $-0.59^{\circ}$ & 0.11 & 0.19 & -0.22 \\
\hline & G.ve & $0.86=*$ & $0.77^{* *}$ & $0.77^{* *}$ & $0.70^{*}$ & .0 .54 & .0 .05 & 0.22 & .0 .26 & $-0.83^{* * 4}$ & -0.21 & $\begin{array}{l}-0.42 \\
0.41\end{array}$ & -0.03 & $0.68^{*}$ & $\begin{array}{l}-0.14 \\
-0.14\end{array}$ & 0.41 \\
\hline & $G+v e$ & $-0.58^{\circ}$ & .0 .52 & .0 .52 & -0.28 & 0.40 & 0.20 & 0.24 & 0.52 & 0.52 & 0.29 & -0.55 & 0.13 & .0 .43 & -0.03 & -0.55 \\
\hline & Mono & $0.80^{\circ}=$ & $0.65^{\circ}$ & $0.65^{\circ}$ & 0.56 & .0 .53 & 0.22 & 0.11 & -0.16 & $-0.67^{\circ}$ & -0.20 & 0.41 & -0.02 & $0.64^{*}$ & .0 .04 & 0.41 \\
\hline & Cyelo & 0.48 & $0.64=$ & $0.64=$ & 0.29 & -0.57 & 0.09 & 0.04 & 0.00 & -0.48 & -0.27 & 0.41 & -0.28 & 0.49 & -0.13 & 0.41 \\
\hline & lso & -0.58 & .0 .53 & .0 .53 & .0 .40 & 0.37 & 0.16 & 0.16 & $0.73^{*}$ & $0.61^{*}$ & 0.18 & -0.55 & 0.05 & -0.46 & 0.04 & $\begin{array}{l}-0.55 \\
\end{array}$ \\
\hline & Anteiso & 0.18 & -0.09 & .0 .09 & 0.25 & -0.28 & 0.01 & 0.46 & 0.31 & -0.11 & 0.06 & $\begin{array}{l}-0.33 \\
-0.49\end{array}$ & 0.44 & $\begin{array}{l}0.080 \\
0.08\end{array}$ & 0.025 & $\begin{array}{l}-0.53 \\
-0.49\end{array}$ \\
\hline & $\begin{array}{l}\text { Ainterso } \\
\text { iso:anteiso }\end{array}$ & $\begin{array}{l}0.18 \\
-0.9700\end{array}$ & $-0.63^{\circ}$ & $-0.63^{\circ}$ & $\begin{array}{l}0.287^{\circ} \\
-0.0\end{array}$ & 0.16 & 0.36 & $\begin{array}{l}0.46 \\
-0.01\end{array}$ & 0.52 & $0.790 \%$ & $\begin{array}{l}0.36 \\
0.35\end{array}$ & $\begin{array}{l}-0.49 \\
-0.14\end{array}$ & -0.20 & -0.53 & $\begin{array}{l}-0.23 \\
-0.18\end{array}$ & $\begin{array}{l}-0.49 \\
-0.14\end{array}$ \\
\hline & Saturated & -0.14 & .0 .07 & .0 .07 & 0.42 & .0 .40 & 0.46 & $0.62^{\circ}$ & -0.05 & .0 .23 & $0.76^{* 0}$ & 0.48 & -0.03 & 0.27 & $.0 .74^{*}$ & 0.48 \\
\hline & S.reducers & -0.21 & 0.08 & 0.08 & 0.56 & -0.34 & $0.75^{\circ}$ & $0.80^{\circ 4}$ & .0 .05 & -0.32 & $0.79^{\circ *}$ & 0.55 & -0.11 & 0.22 & $-0.81 *$ & 0.55 \\
\hline & Anaerobic & $0.60^{\circ}$ & $0.70^{\circ}$ & $0.70^{\circ}$ & 0.37 & -0.46 & 0.00 & -0.06 & -0.31 & $=0.64^{\circ}$ & -0.22 & 0.55 & -0.33 & $0.61^{*}$ & -0.08 & 0.55 \\
\hline & $\mathrm{Mo}: \mathrm{Cy}$ & 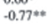 & -0.34 & -0.34 & $\begin{array}{l}-0.32 \\
-0.32\end{array}$ & 0.01 & 0.45 & 0.28 & $0.63^{*}$ & 0.51 & 0.52 & 0.07 & $\begin{array}{l}-0.29 \\
-0.29\end{array}$ & $\begin{array}{l}0.070 \\
-0.20\end{array}$ & $\begin{array}{l}-0.30 \\
-0.30\end{array}$ & 0.07 \\
\hline & PLFAt & $0.83^{=*}$ & 0.37 & 0.37 & 0.45 & -0.06 & -0.50 & -0.09 & -0.41 & -0.52 & -0.55 & -0.27 & 0.50 & 0.20 & 0.33 & -0.27 \\
\hline \multirow{17}{*}{ 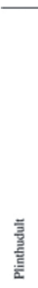 } & Bacteria & -0.43 & $-0.58^{*}$ & .0 .48 & .0 .23 & 0.06 & 0.34 & -0.05 & -0.31 & -0.31 & $0.62^{*}$ & 0.16 & $0.70^{\circ}$ & -0.41 & .0 .53 & 0.00 \\
\hline & Fungi & -0.23 & 0.40 & 0.23 & 0.17 & 0.26 & 0.43 & 0.08 & 0.31 & 0.31 & -0.21 & -0.05 & -0.57 & 0.26 & -0.08 & 0.14 \\
\hline & F:b & 0.03 & -0.48 & -0.23 & -0.18 & -0.10 & -0.13 & -0.34 & -0.10 & -0.10 & 0.05 & -0.01 & 0.33 & -0.39 & -0.10 & -0.41 \\
\hline & Actino & -0.02 & .0 .19 & .0 .01 & -0.05 & .0 .47 & -0.05 & -0.41 & -0.47 & -0.47 & 0.52 & 0.14 & 0.49 & 0.04 & -0.12 & 0.07 \\
\hline & $\begin{array}{l}\text { Accino } \\
\text { Proxozoa }\end{array}$ & $\begin{array}{l}-0.02 \\
0.41\end{array}$ & $\begin{array}{l}-0.19 \\
0.12\end{array}$ & 0.27 & $0.82^{* * *}$ & $\begin{array}{l}-0.47 \\
-0.40\end{array}$ & 0.38 & $\begin{array}{l}-0.71 * \\
0.71 *\end{array}$ & $\begin{array}{l}-0.47 \\
-0.66^{*}\end{array}$ & $\begin{array}{l}-0.41 \\
-0.66^{*}\end{array}$ & $\begin{array}{l}0.52 \\
-0.33\end{array}$ & $0.86^{* 4}$ & $\begin{array}{l}0.49 \\
-0.12\end{array}$ & 0.13 & $\begin{array}{l}-0.12 \\
-0.68^{*}\end{array}$ & $\begin{array}{l}0.07 \\
0.44\end{array}$ \\
\hline & G-ve & -0.45 & $-0.59^{*}$ & -0.56 & $-0.60^{\circ}$ & 0.25 & 0.00 & -0.37 & 0.05 & 0.05 & 0.47 & -0.34 & $0.61^{*}$ & -0.55 & -0.02 & -0.28 \\
\hline & G+ve & -0.07 & -0.22 & .0 .08 & 0.18 & -0.31 & 0.19 & $\begin{array}{l}-0.16 \\
-0.16\end{array}$ & -0.42 & -0.42 & $0.62^{*}$ & 0.31 & 0.40 & 0.09 & -0.44 & 0.14 \\
\hline & Mono & -0.15 & 0.50 & 0.35 & 0.23 & 0.16 & 0.37 & -0.01 & 0.31 & $\begin{array}{l}-0.42 \\
0.31\end{array}$ & -0.21 & -0.05 & $-0.65^{\circ}$ & 0.40 & -0.02 & 0.14 \\
\hline & Cyclo & -0.27 & $-0.67^{*}$ & .0 .48 & .0 .42 & 0.06 & 0.06 & -0.12 & -0.31 & -0.31 & 0.31 & 0.05 & $0.70^{\circ}$ & $-0.59^{\circ}$ & .0 .28 & -0.14 \\
\hline & ISo & 0.01 & -0.18 & -0.01 & 0.27 & -0.47 & 0.18 & -0.05 & -0.52 & -0.52 & 0.52 & 0.43 & 0.45 & 0.10 & -0.46 & 0.14 \\
\hline & Anteiso & -0.39 & 0.20 & 0.02 & .0 .29 & 0.19 & .0 .03 & $-0.63^{\circ}$ & 0.53 & 0.53 & $0.63^{*}$ & -0.52 & -0.12 & 0.39 & 0.31 & -0.14 \\
\hline & isoanteiso & .0 .34 & .0 .05 & .0 .13 & 0.03 & 0.27 & 0.44 & .0 .06 & 0.16 & 0.16 & 0.16 & .0 .04 & .0 .13 & .0 .06 & .030 & 0.00 \\
\hline & Saturated & -0.24 & 0.20 & 0.06 & 0.48 & -0.21 & $0.59^{*}$ & $0.80^{\circ * *}$ & -0.21 & -0.21 & 0.05 & 0.54 & 0.18 & 0.09 & .056 & 0.28 \\
\hline & S.reducers & $\begin{array}{l}-0.24 \\
-0.29\end{array}$ & 0.53 & 0.40 & $\begin{array}{l}0.16 \\
0.16\end{array}$ & $\begin{array}{r}-0.21 \\
-0.19\end{array}$ & 0.21 & -0.43 & $\begin{array}{l}-0.31 \\
0.38\end{array}$ & $\begin{array}{l}-0.21 \\
0.38\end{array}$ & 0.43 & $\begin{array}{l}-0.14 \\
-0.14\end{array}$ & $\begin{array}{l}0.18 \\
-0.31\end{array}$ & $0.70^{*}$ & $\begin{array}{l}-0.50 \\
0.10\end{array}$ & $\begin{array}{l}-0.07 \\
-0.07\end{array}$ \\
\hline & Anacrobic & -0.19 & .0 .58 & -0.44 & .0 .45 & 0.00 & -0.12 & -0.37 & -0.16 & -0.16 & 0.31 & $\begin{array}{l}-0.18 \\
-0.18\end{array}$ & $0.61^{\circ}$ & -0.53 & -0.02 & -0.28 \\
\hline & $\mathrm{MocCy}$ & 0.26 & $0.71^{\circ}$ & 0.54 & 0.52 & .0 .03 & 0.10 & 0.20 & 0.31 & 0.31 & -0.52 & 0.03 & $-0.85^{* *}$ & 0.55 & 0.18 & 0.14 \\
\hline & PLFAI & 0.32 & -0.10 & $\begin{array}{l}-0.02 \\
-0.02\end{array}$ & 0.17 & $\begin{array}{l}-0.35 \\
-0.35\end{array}$ & -0.23 & 0.26 & -0.41 & $-0,41$ & 0.00 & 0.27 & 0.33 & -0.07 & $\begin{array}{l}-0.03 \\
-0.03\end{array}$ & 0.14 \\
\hline
\end{tabular}

F:B (fungal bacterial ratio), Actino (actinomycete), G-ve (Gram negative bacteria), G+ve (Gram positive bacteria), Mono (Monosaturated PLFAs), Cyclo (Cyclopropane), Iso (iso PLFAs), anteiso (anteiso PLFAs), iso:anteiso (iso and anteiso PLFA ratio), S. reduce (sulfate reducers), Mo: Cy ( monosaturated and cyclopropane PLFA ratio)*. Correlation is significant at $\mathrm{p}<0.05$.**. Correlation is significant at $\mathrm{p}<0.01$ 


\section{Conclusions}

Biochar types and application rates to Plinthudult and Psammaquent significantly influence the soil microbial community structure. Specific biochars influenced the particular microbial communities in both soils. Biochars reduced environmental and nutritional stress indicating PLFA concentrations in microbial communities of Psammaquent and increased them in the Plinthudult due to increased available elemental concentrations. Biochars generated from different feedstocks containing higher amount of specific elements, significantly increased the particular available element concentrations in soils. The biochar containing lower concentration of elements significantly reduced the available element concentrations in soils. The biochars containing higher amount of heavy metals, upon addition to soils, containing higher concentrations of the same elements as biochars increased the soil available element concentrations in soils. Study suggests that biochars increasing the nutrients in by reducing their leaching from soils. Therefore, its application can increase the soil fertility consequently can increase the crop productivity.

\section{Acknowledgements}

The authors acknowledge the National Basic Research Program of China (2011CB100502, 2014CB441002) for financial support to this study.

\section{References}

Ameloot, N., De Neve, S., Jegajeevagan, K., Yildiz, G., Buchan, D., Funkuin, Y.N., Prins, W., Bouckaert, L., Sleutel, S. 2013. Short-term $\mathrm{CO}_{2}$ and $\mathrm{N}_{2} \mathrm{O}$ emissions and microbial properties of biochar amended sandy loam soils. Soil Biology and Biochemistry. 57, 401-410.
Asai, H., Samson, B.K., Stephan, H.M., Songyikhangsuthor, K., Homma, K., Kiyono, Y., Inoue, Y., Shiraiwa, T., Horie, T. 2009. Biochar amendment techniques for upland rice production in Northern Laos: 1. Soil physical properties, leaf SPAD and grain yield. Field Crops Research. 111, 81-84.

Bossio, D., Scow, K., Gunapala, N., Graham, K. 1998. Determinants of soil microbial communities: effects of agricultural management, season, and soil type on phospholipid fatty acid profiles. Microbial Ecology. 36, 1-12.

Dai, Z., Meng, J., Muhammad, N., Liu, X., Wang, H., He, Y., Brookes, P.C., Xu, J. 2013. The potential feasibility for soil improvement, based on the properties of biochars pyrolyzed from different feedstocks. Journal of Soils and Sediments. 1-12.

Glaser, B., Lehmann, J., Zech, W. 2002. Ameliorating physical and chemical properties of highly weathered soils in the tropics with charcoal-a review. Biology and Fertility of Soils. 35, 219-230.

Graber, E.R., Harel, Y.M., Kolton, M., Cytryn, E., Silber, A., David, D.R., Tsechansky, L., Borenshtein, M., Elad, Y. 2010. Biochar impact on development and productivity of pepper and tomato grown in fertigated soilless media. Plant and Soil. 337, 481-496.

Haigh, M.J. 1995. Soil quality standards for reclaimed coal-mine disturbed lands: A discussion paper. International Journal of Surface Mining and Reclamation. 9, 187-202.

Hedlund, K. 2002. Soil microbial community structure in relation to vegetation management on former agricultural land. Soil Biology and Biochemistry. 34, 1299-1307.

Jindo, K., Sánchez-Monedero, M.A., Hernández, T., García, C., Furukawa, T., Matsumoto, K., Sonoki, T., Bastida, F. 2012. Biochar influences the microbial community structure during manure composting 
with agricultural wastes. Science of the Total Environment. 416, 476-481.

Jones, D., Edwards-Jones, G., Murphy, D. 2011. Biochar mediated alterations in herbicide breakdown and leaching in soil. Soil Biology and Biochemistry. 43, 804-813.

Kolton, M., Harel, Y.M., Pasternak, Z., Graber, E.R., Elad, Y., Cytryn, E. 2011. Impact of biochar application to soil on the root-associated bacterial community structure of fully developed greenhouse pepper plants. Applied and Environmental Microbiology. 77, 4924-4930.

Kong, A.Y., Scow, K.M., Córdova-Kreylos, A.L., Holmes, W.E., Six, J. 2011. Microbial community composition and carbon cycling within soil microenvironments of conventional, low-input, and organic cropping systems. Soil Biology and Biochemistry. 43, 20-30.

Lehmann, J. 2007. Bio-energy in the black. Frontiers in Ecology and the Environment. 5, 381-387.

Lehmann, J., da Silva Jr, J.P., Steiner, C., Nehls, T., Zech, W., Glaser, B. 2003. Nutrient availability and leaching in an archaeological Anthrosol and a Ferralsol of the Central Amazon basin: fertilizer, manure and charcoal amendments. Plant and Soil. 249, 343-357.

Lehmann, J., Rillig, M.C., Thies, J., Masiello, C.A., Hockaday, W.C., Crowley, D., 2011. Biochar effects on soil biota-a review. Soil Biology and Biochemistry. 43, 1812-1836.

Liang, C., Jesus, E.d.C., Duncan, D.S., Jackson, R.D., Tiedje, J.M., Balser, T.C. 2012. Soil microbial communities under model biofuel cropping systems in southern Wisconsin, USA: impact of crop species and soil properties. Applied Soil Ecology. 54, 24-31.

Marris, E. 2006. Putting the carbon back: Black is the new green. Nature. 442, 624-626.
Mathews, J.A. 2008. Carbon-negative biofuels Energy policy. 36, 940-945.

McCormack, S.A., Ostle, N., Bardgett, R.D., Hopkins, D.W., Vanbergen, A.J. 2013. Biochar in bioenergy cropping systems: impacts on soil faunal communities and linked ecosystem processes. GCB Bioenergy.

McKinley, V., Peacock, A., White, D. 2005. Microbial community PLFA and PHB responses to ecosystem restoration in tallgrass prairie soils. Soil Biology and Biochemistry. 37, 1946-1958.

Muhammad, N., Dai, Z., Wang, H., Xu, F., Xu, J., 2013. Impact of pyrolysis time and temperature on physicochemical characteristics of biochars from wetland Plants, Functions of Natural Organic Matter in Changing Environment. Springer, pp. 1039-1044.

Mutabaruka, R., Hairiah, K., Cadisch, G. 2007. Microbial degradation of hydrolysable and condensed tannin polyphenol-protein complexes in soils from different land-use histories. Soil Biology and Biochemistry. 39, 1479-1492.

Myers, R.T., Zak, D.R., White, D.C., Peacock, A. 2001. Landscape-level patterns of microbial community composition and substrate use in upland forest ecosystems. Soil Science Society of America Journal. 65, 359-367.

Pettersson, M., Baath, E. 2003. Temperaturedependent changes in the soil bacterial community in limed and unlimed soil. Fems Microbiology Ecology. 45, 13-21.

Pietikäinen, J., 0. Kiikkilä., H. Fritze. 2000. Charcoal as a habitat for microbes and its effect on the microbial community of the underlying hummus. Oikos. 89, 1-242.

Preem, J.-K., Truu, J., Truu, M., Mander, Ü., Oopkaup, K., Lõhmus, K., Helmisaari, H.-S., Uri, V., Zobel, M. 2012. Bacterial community structure and its relationship to soil physico-chemical characteristics 
in alder stands with different management histories. Ecological Engineering. 49, 10-17.

Ratledge, C., Wilkinson, S.G., 1988. Microbial lipids. Academic Press London.

Rinnan, R., Bååth, E. 2009. Differential utilization of carbon substrates by bacteria and fungi in tundra soil. Applied and environmental microbiology. $75,3611-3620$.

Shi, W., Becker, J., Bischoff, M., Turco, R., Konopka, A. 2002. Association of microbial community composition and activity with lead, chromium, and hydrocarbon contamination. Applied and Environmental Microbiology. 68, 3859-3866.

Silber, A., Levkovitch, I., Graber, E. 2010. pHdependent mineral release and surface properties of cornstraw biochar: agronomic implications. Environmental Science and Technology. 44, 9318-9323.

Six, J., Elliott, E., Paustian, K., Doran, J. 1998. Aggregation and soil organic matter accumulation in cultivated and native grassland soils. Soil Science Society of America Journal. 62, 1367-1377.

Steiner, C., Das, K.C., Garcia, M., Förster, B., Zech, W. 2008. Charcoal and smoke extract stimulate the soil microbial community in a highly weathered xanthic Ferralsol. Pedobiologia. 51, 359-366.

Steiner, C., Teixeira, W.G., Lehmann, J., Nehls, T., de Macêdo, J.L.V., Blum, W.E., Zech, W. 2007. Long term effects of manure, charcoal and mineral fertilization on crop production and fertility on a highly weathered Central Amazonian upland soil. Plant and Soil. 291, 275-290.

Sun, D., Jun, M., Zhang, W., Guan, X., Huang, Y., Lan, Y., Gao, J., Chen, W. 2012. Implication of temporal dynamics of microbial abundance and nutrients to soil fertility under biochar application - Field experiments conducted in a brown soil cultivated with soybean, north China, in: Iranpour, R., Zhao, J., Wang, A., Yang, F.L., Li, X.
(Eds.), Advances in Environmental Science and Engineering. Pts 1-6, vol. 518-523, pp. 384-394.

Ter Braak, C.J. 1989. CANOCO - an extension of DECORANA to analyze species-environment relationships. Hydrobiologia. 184, 169-170.

Ter Braak, C.J., Prentice, I.C. 1988. A theory of gradient analysis.

Titirici, M.-M., Thomas, A., Antonietti, M. 2007. Back in the black: hydrothermal carbonization of plant material as an efficient chemical process to treat the $\mathrm{CO}_{2}$ problem?. New Journal of Chemistry. 31, 787-789.

Van Ranst, E. 1999. Manual for the soil chemistry and fertility laboratory: Analytical methods for soils and plants equipment and management of consumables. University of Ghent, International Training Centre for Post-Graduate Soil Scientists.

Verheijen, F., Jeffery, S., Bastos, A., Van der Velde, M., Diafas, I. 2010. Biochar application to soils: a critical scientific review of effects on soil properties, processes and functions. Luxembourg: European Commission.

Wu, Y., Ding, N., Wang, G., Xu, J., Wu, J., Brookes, P.C. 2009a. Effects of different soil weights, storage times and extraction methods on soil phospholipid fatty acid analyses. Geoderma. 150, 171-178.

Yuan, J.-H., Xu, R.-K., Zhang, H. 2011. The forms of alkalis in the biochar produced from crop residues at different temperatures. Bioresource Technology. 102, 3488-3497.

Zelles, L., Palojärvi, A., Kandeler, E., Von Lützow, M., Winter, K., Bai, Q. 1997. Changes in soil microbial properties and phospholipid fatty acid fractions after chloroform fumigation. Soil Biology and Biochemistry. 29, 1325-1336.

Zimmerman, A.R. 2010. Abiotic and microbial oxidation of laboratory-produced black carbon (biochar). Environmental Science and Technology. 44, 1295-1301. 